\title{
The Effect of Different Suture Materials on Achilles Tendon Metabolism: A Preliminary in vivo Study of mRNA levels in Rabbits
}

\author{
S. Ergün ${ }^{1}$, A. Alakbarov², A. Mine Yılmaz³ ${ }^{3}$ B. Karademir ${ }^{3}$, U. Akgün ${ }^{1}$ \\ 1 Department of Orthopaedics Surgery, Acıbadem Mehmet Ali Aydınlar University, Istanbul, Turkey \\ 2 Department of Orthopaedics Surgery, Ersoy Hospital, Istanbul, Turkey \\ 3 Department of Biochemistry, School of Medicine / Genetic and Metabolic Diseases Research and Investigation \\ Center, Marmara University, Istanbul, Turkey
}

\section{CORRESPONDING AUTHOR:}

Selim Ergun

Department of Orthopaedics Surgery

Acıbadem Mehmet

Ali Aydınlar University

Istanbul, Turkey

Phone: +905336011472

E-mail: drselimergun@gmail.com

DOI:

10.32098/mltj.04.2019.01

LEVEL OF EVIDENCE: 2B

\begin{abstract}
SUMMARY
Backround. Different suture materials are preferable for the repair of Achilles tendon ruptures. The effect of the sutures on the biological level on a repair scenario is still tentative. The purpose of this study is to show the effects of Vicryl ${ }^{\circledR}$, Ethibond ${ }^{\circledR}$ and PDS ${ }^{\circledR I}$ on Achilles tendons at mRNA levels.

Methods. 36 Achilles tendons of 18 White New Zealand Rabbit were divided into four groups (n:9). Acute tendon rupture model was created and three groups were repaired with each of the aforementioned sutures (fourth was the control group). At day twelve, mRNA was isolated from each tendon, and expression levels of Collagen (COL) 1A2, COL3A1, Decorin, Matrix Metalloproteinase (MMP) 13 and Interleukin (IL) $1 \beta$ were measured quantitatively and compared.

Results. Tendons repaired with PDS ${ }^{\circledR}$ II showed high COL1A2, COL3A1 and decorin expression levels $(\mathrm{p}<0.05)$. MMP-13 expression was high in Ethibond ${ }^{\circledR}$ group when compared with PDS ${ }^{\circledR} \mathrm{II}(\mathrm{p}<0.05)$. High IL-1 $\beta$ expression in tendons repaired with Ethibond ${ }^{\circledR}$ was found $(\mathrm{p}>0.05)$.

Conclusions. Tendons repaired with PDS ${ }^{\circledR} \mathrm{II}$ are found to have superior properties regarding extracellular matrix component synthesis-degradation, and inflammatory cytokine production at mRNA levels when compared to Vicryl ${ }^{\circledR}$ and Ethibond ${ }^{\circledR}$. These results can be a guide to surgeons regarding suture choice in Achilles tendon repairs.
\end{abstract}

KEY WORDS

Achilles; PDS; $m$ RNA; collagen; decorin; MMP-13

\section{BACKGROUND}

Achilles is the largest and strongest tendon in the body and subject to tensile forces of up to 12.5 times body weight (18). It is the third most commonly injured tendon with an incidence of 18 in 100.000, most commonly 4th and 5th decade male patients. Operative or non-operative treatment options for Achilles tendon rupture is in preference of orthopaedic surgeons and the patients (17). Different suture materials and suture techniques are widely used for the repair.

All tendons have a complex and composite architecture composed of collagen fibrils and surrounding decorin and elastin like proteoglycans. In Achilles tendon, collagen type
I alpha chain forms the $65-80 \%$ the tendon's dry weight (18). Collagen type I alpha 1 chain, together with type I alpha 2 chain (COL 1A2), encodes the major component of type I alpha collagen. Collagen type III, which is another constituent of Achilles tendon, functions as a connection in between endotenon and the main collagen fibrils. Type III collagen is localized in the endotenon in normal intact tendon, whereas it is found in the whole tissue after an injury to the tendon, therefore it is assumed that type III collagen plays a role in tissue repair process. Decorin is an important proteoglycan, it is responsible for assembly of extracellular matrix by binding to type I collagen fibers. 
When the Achilles tendon loses the integrity, cellular and tissue response to this trauma cause an increase in the expression of matrix-degrading enzymes and some inflammatory cytokines (11). In literature, studies on rat and rabbit tendons found different expression levels of these enzymes and cytokines (5, 20, 22). Matrix metalloproteinases (MMP) 2, 3, 9, 13 and 14 are important regulators of extracellular matrix remodelling (22). Among these enzymes, MMP-13 mRNA levels were found to increase rapidly after injury and these high levels persisted for a long time (42 days) (5). Besides, MMP-13 was found to participate only in collagen degradation (it is also named as Collagenase III), not in collagen remodelling $(7,20,22)$. With the injury to the tendon tissue, inflammatory phase starts and IL- $1 \beta$ reaches its high levels. IL-1 $\beta$ and MMP-13 are shown to be up regulated following an injury to rat patellar tendons in overusing conditions (23).

Animal tendons are usually good options for the biomechanical, histologic or molecular level experiments, however anatomy of the tendon can be quite different from human tendon anatomy. Doherty et al. showed that, rabbit Achilles tendon has some different anatomic features when compared to human Achilles tendon. The medial and lateral gastrocnemius muscle tendons merged at $93 \%$ of their course from proximal to distal, different from the gastrocnemius human tendons, which merged at $23 \%$ of their overall course. The soleus muscle and tendon are negligible in the rabbit (8). These particular comparative anatomic features are important to consider when using the rabbit as a research model, especially for mechanical testing, however we do not think that this anatomic difference is not important for studies measuring quantitative mRNA levels of different proteins. Suture materials are in close contact with the tendon tissue after the repair and they can trigger some inflammatory reactions $(1,4,14,19)$. Among the suture materials used in Achilles tendon repair, polyglactin $910\left(\right.$ Vicryl $\left.^{\circledR}\right)$, polydioxanone (PDS ${ }^{\circledR} \mathrm{II}$ ) and polyester (Ethibond Excel ${ }^{\circledR}$ ) are the most frequently used ones. However healing response on the biological level is still tentative. There is no data on how tenocyte metabolism is influenced from these different suture materials.

The aim of the present study was to demonstrate in vivo effects of frequently used three different suture materials by quantitavely measuring the synthesis of structural proteins (collagen, decorin), matrix-degrading enzymes (MMP13) and cytokines (IL-1 $\beta$ ) at mRNA levels. We hypothesized that a nonabsorbable polyester suture material may elevate inflammatory mRNA levels due to irritative nature when compared to those of absorbable polyglactin 910 and polydioxanone.

\section{MATERIALS AND METHODS}

20 male White New Zealand rabbits aged between 9-12 months and weighing $2.4-3.4 \mathrm{~kg}$. were recruited in the study. With the approval of the local Ethics Review Board, animals arrived to laboratory two weeks before surgery to allow acclimatization. Animals were provided a standard laboratory diet and water ad libitum. Animals were numbered from 1 to 20 and kept single in cages. Animals were randomly divided into four experimental groups; while right Achilles tendons of animals with an odd number formed group 1 (Vicryl ${ }^{\circledR}$ group), left Achilles tendons formed group 2 (Ethibond Excel ${ }^{\circledR}$ group). Similarly right Achilles tendons of animals with an even number formed group 3 (PDS®II group) and left Achilles tendons formed group 4 (control group).

A single prophylactic intramuscular dose of the antibiotic cephazolin $(100 \mathrm{mg})$ was applied before surgery. Under anesthesia $(100 \mathrm{mg} / \mathrm{kg}$ ketamine $+5 \mathrm{mg} / \mathrm{kg}$ chlorpromazine) and sterile conditions, achillotomy was performed $15 \mathrm{~mm}$ proximal to calcaneal insertion of both Achilles tendons of the rabbits (figure 1a, $\mathbf{b}$ and $\mathbf{c}$ ). Tendon repair was done by modified Kessler's technique with different suture materials in groups 1, 2 and 3 (figure 1d). Repair was done with 2/0 Vicry ${ }^{\circledR}$ (round-tip, $1 / 2$ circle, 26-mm needle) in group 1 , 2/0 Ethibond Excel ${ }^{\circledR}$ (round-tip, 1/2 circle, 26-mm needle) in group 2 and 2/0 PDS ${ }^{\circledR} \mathrm{II}$ (round-tip, 1/2 circle, 26-mm needle) in group 3. Cut tendon was not repaired and left to secondary healing in control group. After closure of the wound (figure 1e), short leg casting in plantar flexion was done to all groups (figure 1f).

All animals were sacrificed at day twelve. Choice of $12^{\text {th }}$ day is based on high collagen remodelling and MMP-13 levels seen in between $7^{\text {th }}-14^{\text {th }}$ days by Oshiro et al. (15). Achilles tendons were exposed through the same incision line. In the first three groups, tendon tissue which was in close contact with suture material was excised. In control group, secondary healing tissue between tenotomy ends was excised. All specimens were shaved in 20 micron $(\mu \mathrm{m})$ thick by a cryostat microtome. Following the addition of Qiazol Lysis Reagent ${ }^{\circledR}$, homogenization was performed by using a polytron homogenizer. The supernatant after centrifugation was used for mRNA isolation by using an mRNA isolation kit (Qiagen Rneasy Mini $\mathrm{Kit}^{\circledR}$ ). The concentration of mRNA from each sample was measured using a nanodrop spectrophotometer. Concentrated mRNA solutions were diluted further in order to provide $200 \mathrm{ng} \mathrm{mRNA} /$ microliter $(\mu \mathrm{L})$ of each sample.

RNAs of all groups were converted into cDNA by using reverse transcriptase enzyme. This was followed by quantitative RT-PCR (Real Time Polymerase Chain Reaction) protocol by the measurement of sybr green fluorescence of PCR products. Primers that were used to determine the 


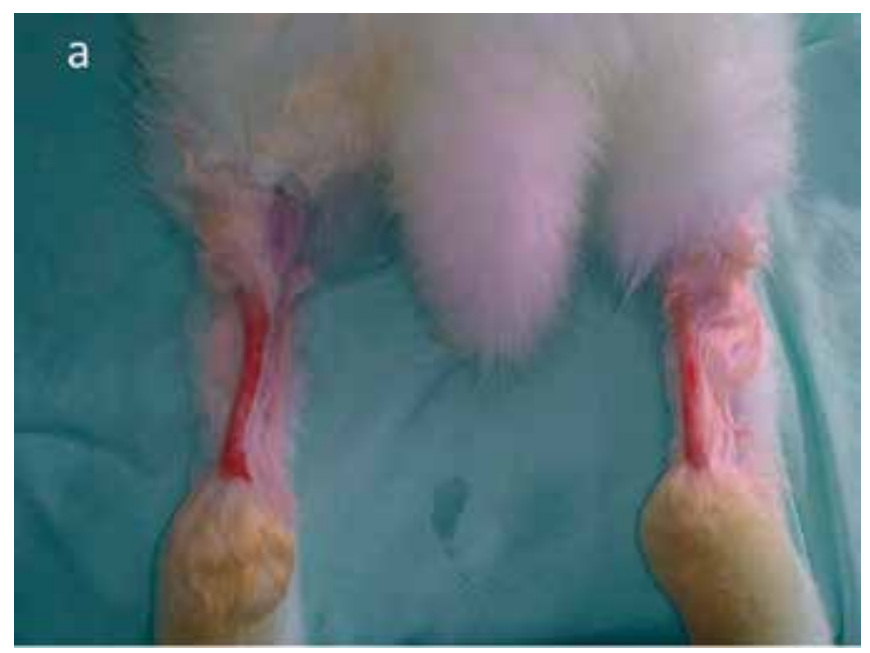

\section{$\mathrm{b}$}
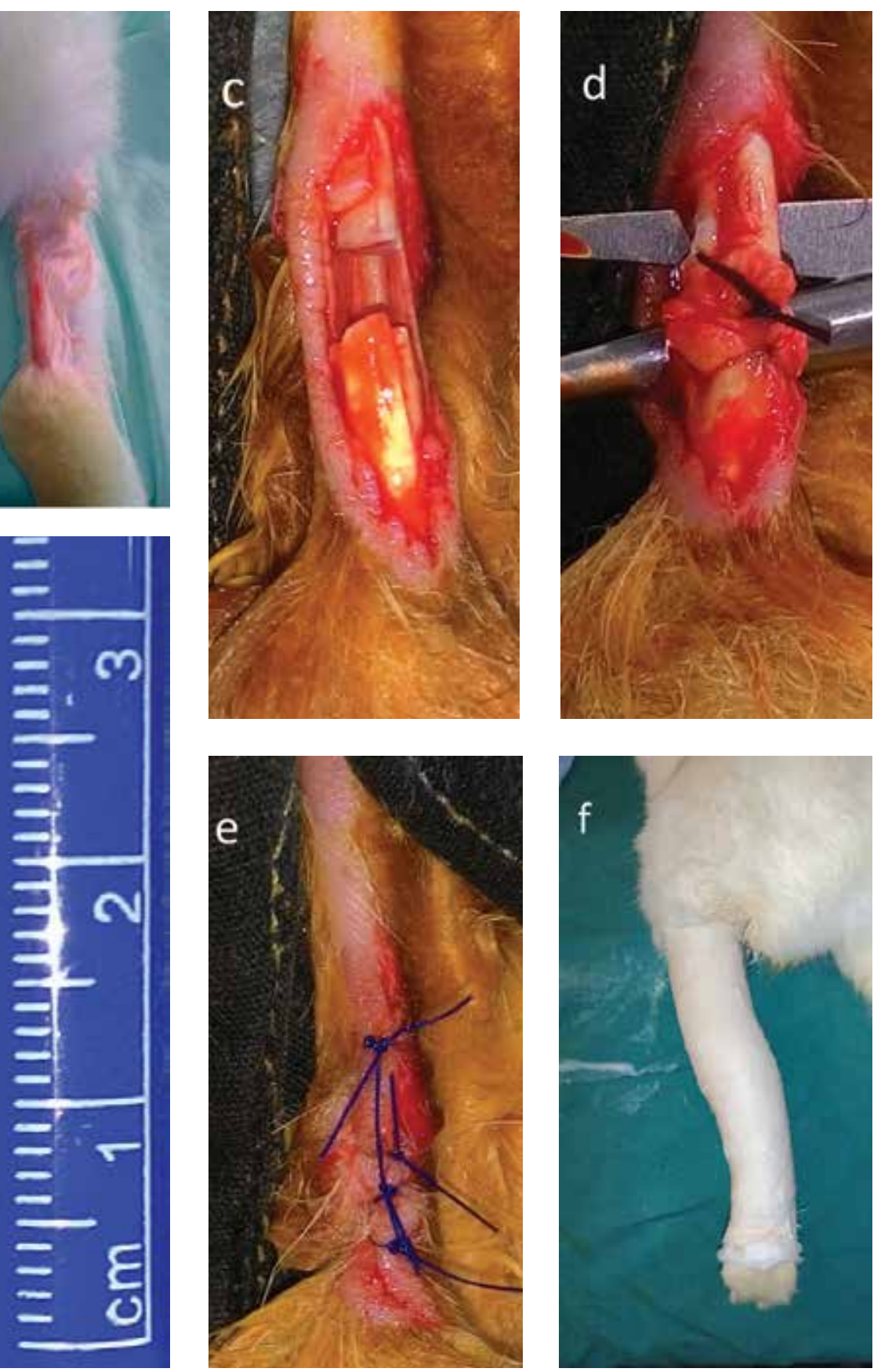

Figure 1. Stages of procedure: a) Lower extremity of rabbit after shaving. $b$ and c) Tenotomy is done $15 \mathrm{~mm}$ proximal to Achilles tendon insertion. d) Repair by modified Kessler's method. e) Skin closure with 3/0 polyproplene. f) Casting in plantar flexion.

mRNA levels of collagen type I alpha 2 chain, collagen type III alpha 1 chain, decorin, MMP-13 and IL-1 are shown in table I. $\beta$-Actin mRNA expression was used as a housekeeping gene to quantify relative mRNA levels.
Quantitative RT-PCR was performed in three steps including denaturation $\left(90-95^{\circ} \mathrm{C}\right)$, primer binding $\left(57-60^{\circ} \mathrm{C}\right)$ and extension $\left(70-75^{\circ} \mathrm{C}\right) .2^{-\Delta \Delta \mathrm{CT}}$ formula in the guidance of $\beta$-actin housekeeping is used for calculation of mean values and 
Table I. Base sequences and melting degrees of the primers used in the quantitative PCR analysis. Primers were selected according to the Primer 3 Output program.

\begin{tabular}{|c|c|c|c|}
\hline GENE & $\begin{array}{l}\text { Primer Sequences } \\
\text { (ORYCTALAGUS CUNICULUS) } \\
\text { (forward/reverse) }\end{array}$ & $\begin{array}{l}\text { Product Size } \\
\text { (base pair) }\end{array}$ & $\begin{array}{l}\text { Annealing } \\
\text { Temperature }(\mathrm{oC})\end{array}$ \\
\hline Collagen 1A2 & $\begin{array}{l}\text { Left primer: AACTTGCCTTCATGCGTCTG } \\
\text { Right primer: CCTCGGCAACAAGTTCAACA }\end{array}$ & $153 \mathrm{bp}$ & $57^{\circ} \mathrm{C}$ \\
\hline Collagen 3A1 & $\begin{array}{l}\text { Left primer: GTCAACCAGTACAAGTGACCA } \\
\text { Right primer: AGCACCATTGAGACATTTTGAAA }\end{array}$ & $175 \mathrm{bp}$ & $60^{\circ} \mathrm{C}$ \\
\hline MMP-13 & $\begin{array}{l}\text { Left primer: CTGCCCCTCCTCAACAGTAA } \\
\text { Right primer: CCTGTCACCTCTAAGCCGAA }\end{array}$ & $185 \mathrm{bp}$ & $57^{\circ} \mathrm{C}$ \\
\hline IL-1 $\beta$ & $\begin{array}{l}\text { Left primer: AAGGAGAGCTCTTTCCCACC } \\
\text { Right primer: GCCTCTGGTCTCCTTGGATT }\end{array}$ & $220 \mathrm{bp}$ & $60^{\circ} \mathrm{C}$ \\
\hline
\end{tabular}

standard deviations of the groups. According to $2^{-\Delta \Delta C T}$ method, control group is always calculated as ' 1 '.

In order to verify that replication products are the copies of the relevant genes (not primer-dimers), RT-PCR products were run on agarose gel electrophoresis and band appearances were visualized under ultraviolet light.

One-Way ANOVA method was used in the comparison of quantitative data between the groups. Tukey test was used for post-hoc analysis. The results were expressed within $95 \%$ confidence interval and the level of statistical significance was set at $\mathrm{p}<0.05$.

\section{RESULTS}

Two animals (one with an odd, other with an even number) died in the postoperative period during the study, thus total number of animals decreased to 18 (9 samples in each group). At the end of day 12 , casts were removed and neither infection nor wound site complication was seen in any group. With the exposure of the tendon tissue, any gap formation or pull-out in the tendon-suture complex was not seen in groups 1, 2 and 3. In group 4, secondary healing tissue was seen in between cut tendon ends of all samples. According to quantitative RT-PCR data, mRNA expressions of genes encoding the structural proteins (COL1A2, COL3A1 and decorin) were found to be highest in PDS ${ }^{\circledR I}$ group. The expression of mRNA for COL1A2 gene was $1.02 \pm 0.32$ in the PDS ${ }^{\circledR}$ II group, $0.42 \pm 0.23$ in the Ethibond Excel ${ }^{\circledR}$ group and $0.35 \pm 0.18$ in the Vicryl ${ }^{\circledR}$ group.
High value in the PDS ${ }^{\circledR}$ II group was significant $(p<0.01)$ when compared with Ethibond Excel ${ }^{\circledR}$ group (mean difference $=0.59, \% 98.4$ confidence interval $(0.12-1.07)$ ) and, Vicryl ${ }^{\circledR}$ group (mean difference $=0.67, \% 98.4$ confidence interval (0.19-1.15)). However there was no significant difference in between Vicry ${ }^{\circledR}$ and Ethibond Excel ${ }^{\circledR}$ groups (figure 2a). The expression of mRNA for COL3A1 gene was $0.54 \pm 0.16$ in the PDS ${ }^{\circledR} \mathrm{II}$ group, $0.39 \pm 0.31$ in the Ethibond Excel $^{\circledR}$ group and $0.22 \pm 0.08$ in the Vicryl ${ }^{\circledR}$ group. High value in the PDS ${ }^{\circledR}$ II group was significant $(p<0.05)$ only when compared with the Vicryl ${ }^{\circledR}$ group (mean difference $=0.32, \% 95$ confidence interval $(0.003-0.63))$, however there was no significant difference in between neither PDS $^{\circledR} \mathrm{II}$ and Ethibond Excel ${ }^{\circledR}$, nor Vicryl ${ }^{\circledR}$ and Ethibond Excel ${ }^{\circledR}$ groups (figure $\mathbf{2 b}$ ). The expression of mRNA for decorin gene was $1.20 \pm 0.45$ in the PDS ${ }^{\circledR} \mathrm{II}$ group, $0.38 \pm 0.12$ in the Ethibond Excel ${ }^{\circledR}$ group and $0.29 \pm 0.23$ in the Vicryl ${ }^{\circledR}$ group. High value in the PDS ${ }^{\circledR}$ II group was significant $(\mathrm{p}<0.01)$ when compared with Ethibond Excel ${ }^{\circledR}$ group (mean difference $=0.82, \% 98.4$ confidence interval (0.17-1.47)), and Vicry ${ }^{\circledR}$ group (mean difference $=0.92$, $\% 98.4$ confidence interval (0.26-1.56)). However, there was no significant difference in between Vicryl ${ }^{\circledR}$ and Ethibond Excel ${ }^{\circledR}$ groups (figure 2c).

The expression of mRNA for MMP-13 was $1.15 \pm 0.74$ in the Ethibond Excel ${ }^{\circledR}$ group, $0.52 \pm 0.30$ in the Vicry ${ }^{\circledR}$ group and $0.23 \pm 0.12$ in the $\mathrm{PDS}^{\circledR} \mathrm{II}$ group. Low value in the PDS ${ }^{\circledR} \mathrm{II}$ group was significant $(\mathrm{p}<0.05)$ only when compared with the Ethibond Excel ${ }^{\circledR}$ group (mean difference=0.92, \%98.4 

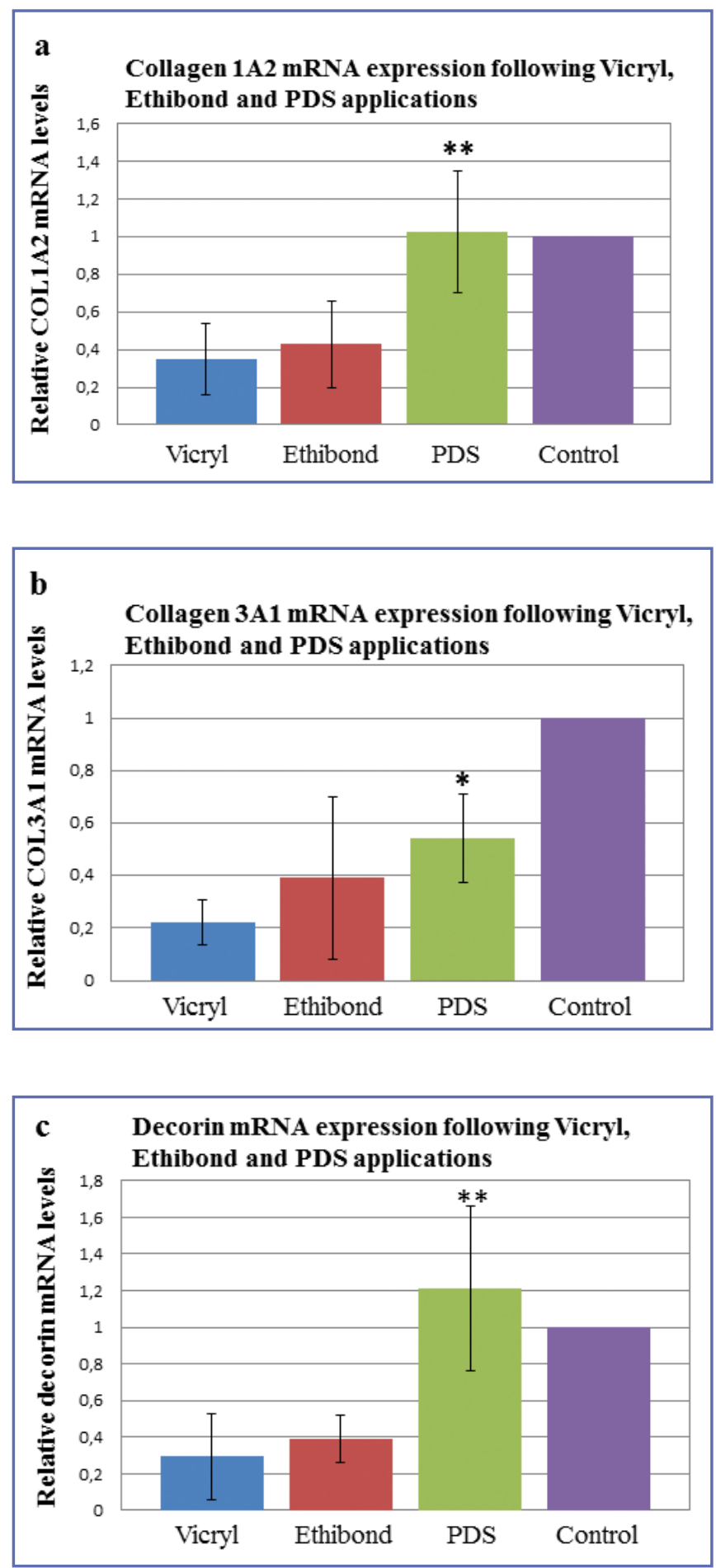

Figure 2. Mean mRNA expression ratios of proteins: a) COL1A2 ${ }^{* *} \mathrm{p}<0.01 \mathrm{PDS}^{\circledR} \|$ versus Vicryl ${ }^{\circledR}$ and Ethibond Exce $\left.{ }^{\circledR}\right)$, b) $\operatorname{COL3A1~}\left({ }^{\star} p<0.05\right.$ PDS $^{\circledR} \|$ versus only Vicryl $\left.{ }^{\circledR}\right)$, and c) Decorin $\left({ }^{* *} p<0.01\right.$ PDS $^{\circledR} \mid l$ versus Vicryl ${ }^{\circledR}$ and Ethibond Excel $^{\circledR}$ ). confidence interval (0.57-1.77)), however there was no significant difference in between neither PDS ${ }^{\circledR} \mathrm{II}$ and Vicry ${ }^{\circledR}$, nor Vicryl ${ }^{\circledR}$ and Ethibond Excel ${ }^{\circledR}$ groups (figure 3).

The expression of mRNA for IL- $1 \beta$ was $1.58 \pm 0.96$ in the Ethibond Excel $^{\circledR}$ group, 1.35 \pm 1.09 in the PDS ${ }^{\circledR}$ II group and $1.03 \pm 0.60$ in the Vicryl ${ }^{\circledR}$ group, but no significant difference was found in between any group (figure 4).

\section{DISCUSSION}

The present study showed that three different suture materials have different effects on the Achilles tendon metabolism. According to the data, repairing Achilles tendon with PDS ${ }^{\circledR} I I$ instead of Vicry ${ }^{\circledR}$ or Ethibond Excel ${ }^{\circledR}$, favourably affects tendon metabolism and results in reduced synthesis of proteases responsible for collagen breakdown, confirming our hypothesis.

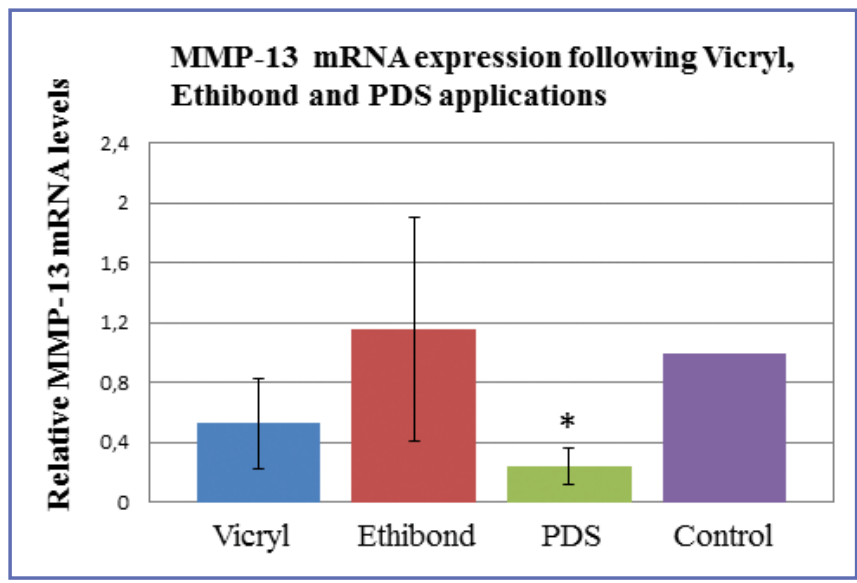

Figure 3. Mean mRNA expression ratios of MMP-13 $\left({ }^{*} \mathrm{p}<0.05\right.$ PDS $^{\circledR} \|$ versus Ethibond Exce $\left.^{\circledR}\right)$.

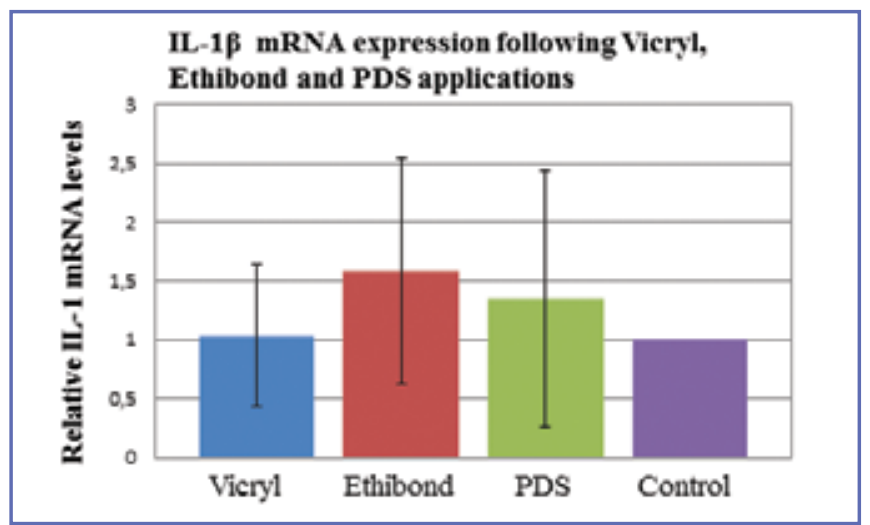

Figure 4. Mean mRNA expression ratios of IL-1 $\beta$ (No significant difference found in between any group).

Muscles, Ligaments and Tendons Journal 2019;9 (4) 
The present study was carried out on rabbits because rabbits have been used for translational studies of Achilles tendon repair using a variety of techniques and therapeutics for several decades (24). Their size allows for clinically relevant operative technique, and they can easily be manipulated to control post-operative rehabilitation through casting. A quantitative RT-PCR method was used to measure the levels of mRNA expressions in order to compare Achilles tendon groups repaired with different suture materials. There are studies in the literature that used similar measurement methods to evaluate tendon metabolism $(2,5,12,13$, 15, 20, 23). Karousou et al. studied the extracellular matrix of 19 ruptured human Achilles tendons and compared the composition of specimens harvested close to the rupture with specimens harvested from an apparently healthy area in the same tendon (15). They compared expression levels of collagen type I, decorin, and versican including enzymes involved in their metabolism as matrix metalloproteases (MMP-2 and -9) and tissue inhibitory of metalloproteinase (TIMP-1 and -2) using real-time PCR, zymography and FACE (fluorophore-assisted carbohydrate electrophoresis) analysis. They found an overall significant increase in the expression of all these genes together with the inflammation at the rupture site when compared to healthy area.

Sun et al. created in vivo degenerative tendon model in the rat patellar tendon and found an interrelated increase in MMP-13 and IL-1 $\beta$ expressions in tendon tissue (23). In a similar way, we looked for IL-1 $\beta$ and MMP-13 expression levels in all groups and found that both genes were highly expressed in tendons repaired with Ethibond Excel ${ }^{\circledR}$ when compared with other suture material groups.

Gold standard suture material in the repair of Achilles tendon is still a matter of debate. Studies about this issue are mostly focused on factors such as holding strength - pullout strength or suture strength - suture endurance. In this regard, Cook et al. compared 2-0 Fiberloop (UHMWPE; Ultra High Moleculer Weight Polyethilene) and \#2 Ethibond Excel ${ }^{\circledR}$ suture materials on Achilles tendon of cadaver (6). There are also studies that simultaneously evaluated suture materials and suture techniques. In a study conducted on cattle Achilles tendon, Yamagami et al. compared 16 tendon repair groups by combining Fiberwire (UHMWPE), Ethibond Excel ${ }^{\circledR}$, PDS $^{\circledR}$ II and Prolene suture materials with four different suture techniques (single locking, multiple locking, single grasping and multiple grasping technique) (25). Petri et al. compared 9 tendon repair groups by combining PDS ${ }^{\circledR} I$, Ethibond Exce ${ }^{\circledR}$ and Fiberwire suture materials with three different suture techniques (Baseball, Kessler and Hannover) on cadaver hamstring tendons (21). However, although these studies provide information about holding capacity and pull-out strength of different suture materials, all are in vitro studies and provide information only about instantaneous tensile strength at time zero. As is known, suture material used in Achilles tendon repair must be resistant to tension forces during postoperative healing and rehabilitation periods. However, the reason for failed surgery may not be always due to pure mechanical causes such as error in suturing technique or suture fail. Under some circumstances, strong suture materials may be pulled out of tendon tissue which is weakened due to inflammation (26). This weakness in tendon structure, starting with the inflammatory process and persisting until day 21 , may cause $70 \%$ decrease in suture holding capacity and have been considered responsible for suture pull-out (27).

$\mathrm{PDS}^{\circledR} \mathrm{II}$ is a rapid absorbable monofilament suture material and loses its strength by $20 \%$ at 2 weeks and by $40 \%$ at 6 weeks. These features are considered disadvantages in the repair of Achilles tendon which is exposed to strong tensile forces. But PDS ${ }^{\circledR} \mathrm{II}$ is also known to have advantages; it is associated with minimum trauma to the tissue during surgery. In an animal study on sheep Achilles tendon has shown that PDS®II has higher holding strength on the tendon when compared with Prolene, Vicryl ${ }^{\circledR}$ and Ethibond Excel ${ }^{\circledR}$ (28). In addition, as a monofilament suture material, it is less likely to promote bacterial adhesion compared with braided sutures. The loss of tensile strength in the early period might be seen as a disadvantage for absorbable sutures; however, complete elimination of these sutures can be considered as an advantage in terms of foreign body reaction.

Oshiro et al. looked for expressions of different genes at different days after repair of precut flexor digitorum longus tendon (using $9 / 0$ nylon) on rats. They found that gene expression of type I collagen decreased initially and then returned gradually to the initial level by day 28. MMP-9 and MMP-13 gene expressions were both found at maximum levels between post-operative days 7 and 14, and participated only in collagen degradation, not in remodeling (20). In the present study, MMP-13 gene expression was measured at day 12 and the amount of its expression was found to be significantly higher in the Ethibond Excel ${ }^{\circledR}$ group when compared with the PDS ${ }^{\circledR} I I$ group. In another study that measured MMP-13 gene expression, Berglund et al. repaired precut rabbit flexor digitorum tendons with $6 / 0$ PDS ${ }^{\circledR I}$ and they found constantly high MMP-13 expression levels (including day 42) (5). Berglund lean the different MMP-13 expression levels with Oshiro's study on the fact that Oshiro immobilized the rats after surgery while Berglund et al. did not. However, they didn't mention about the use of different suture materials in these studies. It must be kept in mind that the difference may have resulted from the use of Nylon in one study and PDS ${ }^{\circledR} I I$ in the other. 
The study by Esenyel et al. conducted on rabbits is the only in vivo experimental study comparing the effects of different suture materials on Achilles tendon repair (10). They evaluated histologic inflammatory response at postoperative $3^{\text {rd }}$ and $6^{\text {th }}$ weeks in tendons repaired with Prolen, Ethibond Excel $^{\circledR}$ and Fiberwire ${ }^{\circledR}$ (UHMWPE) suture materials and compared the extent of inflammatory areas measured under microscopy. They found the largest inflammatory response at $3^{\text {rd }}$ week in the Ethibond Excel ${ }^{\circledR}$ group. This finding is consistent with the current study that found the highest MMP-13 and IL1 $\beta$ response in the Ethibond Excel ${ }^{\circledR}$ group at 12 days.

An observational study was conducted by Kocaoglu et al. to prospectively evaluate the effect of different suture materials used in human Achilles tendon repair surgeries (16). Forty-eight patients were treated with minimal invasive surgical repair method with the diagnosis of spontaneous Achilles tendon rupture, half was repaired by Vicryl ${ }^{\circledR}$ and remain was repaired by Ethibond Excel ${ }^{\circledR}$. Functional status has been verbally compared and no significant difference was found between these two groups. However, the rate of complications such as recurrent rupture, foreign body reaction and deep infection was significantly lower in the Vicryl ${ }^{\circledR}$ group.

Severe inflammatory response to suture material following Achilles tendon repair has been presented in the form of case reports. Ahluwalia et al. reported a case of Achilles tendon rupture repaired with modified Kessler's method using Ethibond Excel ${ }^{\circledR}$ in which a superficial rash has occurred 3 weeks after surgery and continued with chronic sinus development (1). Baig et al. showed in their prospective clinical study that Achilles tendons repaired with PDS provided fewer wound complications when compared to Achilles tendons repaired with Ethibond Excel ${ }^{\circledR}$ which is confirming our finding (3). Authors reported that this complication is related with the usage of Ethibond Excel ${ }^{\circledR}$. Kara et al. reported a different complication related to the

\section{REFERENCES}

1. Ahluwalia R, Zourelidis C, Guo S, Dega R (2013) Chronic sinus formation using non absorbable braided suture following open repair of Achilles tendon. Foot Ankle Surg. 19(2):7-9.

2. Ahmed AS1, Schizas N, Li J, Ahmed M, Östenson CG, Salo P, Hewitt C, Hart DA, Ackermann PW. (2012) Type 2 diabetes impairs tendon repair after injury in a rat model. J Appl Physiol. 113(11):1784-91.

3. Baig MN, Yousaf I, Galbraith JG, Din R (2017) Absorbable Polydioxanone (PDS) suture provides fewer wound complications than polyester (ethibond) suture in acute Tendo-Achilles rupture repair. Ir Med J. 10;110(5):566. usage of Ethibond Excel ${ }^{\circledR}$ for Achilles tendon repair (14). They reported excessive inflammatory response and development of granuloma and fistula at the fourth month of operation. Sometimes delayed inflammatory response might be seen due to suture material as Ergin et al. reported a case of suture (silk-nonabsorbable-braided) granuloma 30 years following Achilles tendon repair (9). A similar case was reported by Ollivere et al. in which granulomatous reaction has occurred following Achilles tendon rupture using Fiberwire suture material (19). Complications related to Vicryl ${ }^{\circledR}$ usage is also present in literature; Bekler et al. reported early and late aseptic drainage that occurred in four different cases following Achilles tendon repair using Vicryl ${ }^{\circledR}$ suture material (4).

To our knowledge, this is the first study in literature that evaluated the metabolic and inflammatory effects of different suture materials on Achilles tendon at molecular level. The limitations of the study include that we only used three different suture materials, however there are more than ten different suture materials available to use in Achilles tendon repair. Besides, study includes only one method, which is quantitative real-time PCR. No supportive finding regarding tendon's biomechanical quality, histology, or protein content is present. Lastly, Achilles tendon injury model created in this study is somewhat different from what we encounter in clinical routine; the tendon was cut, not ruptured, and a time-zero tendon repair was performed.

Our study is a preliminary study and in conclusion, Achilles tendons repaired with PDS ${ }^{\circledR} \mathrm{II}$ are found to have superior properties regarding extracellular matrix component synthesis and degradation, and produce less inflammatory cytokine at mRNA levels when compared to Vicryl ${ }^{\circledR}$ and Ethibond Excel ${ }^{\circledR}$.

\section{CONFLICT OF INTERESTS}

The authors declare that they have no conflict of interests
4. Bekler HI, Beyzadeoğlu T, Gökçe A, Servet E (2008) Aseptic drainage associated with polyglactine sutures used for repair of Achilles tendon ruptures. Acta Orthop Traumatol Turc. 42(2):135-8.

5. Berglund ME, Hart DA, Reno C, Wiig M (2011) Growth factor and protease expression during different phases of healing after rabbit deep flexor tendon repair. J Orthop Res. 29(6):886-92.

6. Cook KD, Clark G, Lui E, Vajaria G, Wallace GF (2010) Strength of braided polyblend polyethylene sutures versus braided polyester sutures in Achilles tendon repair: a cadaveric study. J Am Podiatr Med Assoc. 100(3):185-8. 
7. Del Buono A, Oliva F, Osti L, Maffulli N (2013) Metalloproteases and tendinopathy. Muscles Ligaments Tendons J. 21;3(1):51-7.

8. Doherty GP, Koike Y, Uhthoff HK, Lecompte M, Trudel G (2006) Comparative anatomy of rabbit and human achilles tendons with magnetic resonance and ultrasound imaging. Comp Med. 56(1):68-74.

9. Ergin ÖN, Demirel M, Özmen E (2017) An Exceptional Case of Suture Granuloma 30 Years Following an Open Repair of Achilles Tendon Rupture: A Case Report. J Orthop Case Rep. 7(3):50-53.

10. Esenyel CZ, Demirhan M, Kiliçoğlu O, Adanir O, Bilgiç B, Güzel O, Ozsoy S (2009) Evaluation of soft tissue reactions to three nonabsorbable suture materials in a rabbit model. Acta Orthop Traumatol Turc. 43(4):366-72.

11. Freedman BR, Gordon JA, Soslowsky LJ (2014) The Achilles tendon: fundamental properties and mechanisms governing healing. Muscles Ligaments Tendons J. 14;4(2):245-55.

12. Graham P. Riley, Valerie Curry, Jeroen DeGroot, Benno van El, Nicole Verzijl, Brian L. Hazleman, Ruud A. Bank (2002) Matrix metalloproteinase activities and their relationship with collagen remodelling in tendon pathology. Matrix Biology. 21:185-195.

13. Jones GC, Corps AN, Pennington CJ, Clark IM, Edwards DR, Bradley MM, Hazleman BL, Riley GP. Expression profiling of metalloproteinases and tissue inhibitors of metalloproteinases in normal and degenerate human achilles tendon. Arthritis Rheum. 2006;54(3):832-42.

14. Kara A, Celik H, Seker A, Uysal MA, Uzun M, Malkoc M (2014) Granuloma formation secondary to Achilles tendon repair with nonabsorbable suture. Int J Surg Case Rep. 5(10):720-2.

15. Karousou E, Ronga M, Vigetti D, Passi, A, Maffulli N (2008) Collagens, proteoglycans, MMP2,MMP9 and TIMPs in human achilles tendon rupture. Clin Orthop Relat Res. 466(7):1577-82.

16. Kocaoglu B, Ulku TK, Gereli A, Karahan M, Turkmen M (2015) Evaluation of absorbable and nonabsorbable sutures for repair of achilles tendon rupture with a suture-guiding device. Foot Ankle Int. 36(6):691-5.

17. Maffulli G, Buono AD, Richards P, Oliva F, Maffulli N (2017) Conservative, minimally invasive and open surgical repair for management of acute ruptures of the Achilles tendon: a clinical and functional retrospective study. Muscles Ligaments Tendons J.10;7(1):46-52.
18. Nickisch F (2009) Anatomy of the Achilles Tendon. In: Nunley JA (ed) The Achilles Tendon Treatment and Rehabilitation. Springer New York, pp 3-16.

19. Ollivere BJ, Bosman HA, Bearcroft PW, Robinson AH (2014) Foreign body granulomatous reaction associated with polyethelene 'Fiberwire(®)' suture material used in Achilles tendon repair. Foot Ankle Surg. 20(2):27-9.

20. Oshiro W1, Lou J, Xing X, Tu Y, Manske PR (2003) Flexor tendon healing in the rat: a histologic and gene expression study. J Hand Surg Am. 28(5):814-23.

21. Petri M, Ettinger M, Dratzidis A, Liodakis E, Brand S, Albrecht UV, Hurschler C, Krettek C, Jagodzinski M (2012) Comparision of three suture techniques and three suture materials on gap formation and failure load in ruptured tendons: a human cadaveric study. Arch Orthop Trauma Surg. 132(5):649-54.

22. Sharma P, Mafulli N (2006) Biology of tendon injury: healing, modeling and remodeling. J Musculoskelet Neuronal Interact. 6(2):181-190.

23. Sun HB, Li Y, Fung DT, Majeska RJ, Schaffler MB, Flatow EL (2008) Coordinate regulation of IL-1beta and MMP-13 in rat tendons following subrupture fatigue damage. Clin Orthop Relat Res. 466(7):1555-61.

24. Thomopoulos S, Parks WC, Rifkin DB, Derwin KA (2015) Mechanism of Tendon Injury and Repair. Journal of Orhopaedic Research. 33: 832-39.

25. Yamagami N, Mori R, Yotsumoto T, Hatanaka H, Takao M, Uchio Y (2006) Biomechanical differences resulting from the combination of suture materials and repair techniques. J Orthop Sci. 11(6):614-9

26. Yildirim Y, Esemenli T. Initial pull-out strength of tendon sutures: an in vitro study in sheep Achilles tendon. Foot Ankle Int 2002;23(12):1126-30.

27. Yildirim Y, Kara H, Cabukoglu C, Esemenli T (2006) Suture holding capacity of the Achilles tendon during the healing period: an in vivo experimental study in rabbits. Foot Ankle Int. 27(2):121-4.

28. Yildirim Y, Saygi B, Kara H, Cabukoğlu C, Esemenli T. Tendon holding capacities of the suture materials used in repairing Achilles tendon rupture (2006) Acta Orthop Traumatol Turc. 40(2):164-8. 